\title{
PRIMERJAVA POLETNE ONESNAŽENOSTI ZRAKA Z DUŠIKOVIM DIOKSIDOM V LJUBLJANI MED LETOMA 2005 IN 2013
}

\author{
dr. Matej Ogrin, dr. Katja Vintar Mally
}

Oddelek za geografijo, Filozofska fakulteta Univerze v Ljubljani

Aškerčeva 2, SI-I000 Ljubljana

e-mail: matej.ogrin@ff.uni-lj.si, katja.vintar@ff.uni-lj.si

\section{Izvirni znanstveni članek}

COBISS 1.01

DOI: $10.4312 /$ dela.40.4.55-72

\section{Izvleček}

V Ljubljani je glavni vir onesnaževanja zraka $\mathrm{z} \mathrm{NO} 2$ promet, zato se prispevek osredotoča na prometno obremenjevanje zraka $v$ treh različnih tipih mestnega prostora: urbanem ozadju, na odprtem prostoru ob cestah in v cestnih koridorjih. Predstavljene so tudi meritve koncentracij prečno na glavno cesto. Prispevek primerja rezultate meritev $\mathrm{NO}_{2} \mathrm{~V}$ Ljubljani v merilnih obdobjih poleti 2005 in 2013 ter skuša pojasniti vzroke za razlike v obsegu onesnaženosti različnih tipov mestnega prostora in pomemben upad koncentracij v vseh obravnavanih tipih.

Ključne besede: onesnaževanje zraka, kakovost zraka, tipi mestnega prostora, dušikov dioksid, difuzivni vzorčevalnik, Ljubljana

\section{THE COMPARISON OF SUMMER AIR POLLUTION BY NITROGEN DIOXIDE IN LJUBLJANA BETWEEN 2005 AND 2013}

\begin{abstract}
In Ljubljana, the air pollution by $\mathrm{NO}_{2}$ is mainly caused by transportation. The article focuses on traffic-related air pollution in three different types of urban space: urban background, open space near the roads, and street canyon. The measurement of concentrations perpendicular to the main city street is also presented. We compare the results of $\mathrm{NO}_{2}$ measuring campaigns in Ljubljana during the summers of 2005 and 2013. We seek to explain the reasons for the differences in the pollution of diverse urban space types and for the significant decrease of concentrations in all types of urban space.
\end{abstract}

Key words: air pollution, air quality, types of urban space, nitrogen dioxide, diffusive samplers, Ljubljana 


\section{UVOD}

Kakovost zraka določenega območja je odvisna od stopnje obremenjevanja in sposobnosti regeneracije oziroma samočistilnih sposobnosti. Obremenjevanje oziroma onesnaževanje ozračja lahko povzročijo naravni procesi, kot so vulkanski izbruhi, požari ali peščeni viharji, lahko pa so vzrok antropogene dejavnosti, npr. promet, industrija, energetika, kmetijstvo, turizem in podobno. Vendar nam obremenjevanje pove le, na kakšen način in kako močno onesnažujemo ozračje, ne pa tudi, v kolikšni meri je zrak na nekem območju dejansko onesnažen. Stopnja onesnaženosti je odvisna še od stanja ozračja, to pa od geografskih značilnosti prostora in meteoroloških pogojev v ozračju. Med prve uvrščamo relief, reliefno energijo, vertikalno razčlenjenost območja, pozidanost tal in podobno, med druge spadajo denimo prevetrenost in stabilnost ozračja ter pogostnost padavin in temperaturnih inverzij. V dolinskih in kotlinskih območjih s slabo prevetrenostjo in pogostimi temperaturnimi inverzijami lahko že razmeroma majhni do zmerni izpusti onesnaževal povzročijo zmerno do veliko onesnaženost ozračja, obratno pa v prevetrenih odprtih območjih z veliko dinamiko vremenskih procesov veliki izpusti povzročajo le majhno do zmerno onesnaženje.

Mestna območja so navadno območja koncentracije virov onesnaževanja, saj se v njih zgoščujejo poselitev in številne družbene dejavnosti. Ni naključje, da prve omembe težav z onesnaženim zrakom izhajajo prav iz mestnih območij. V antični Grčiji so bili voditelji odgovorni za to, da so vire močnejših vonjav razmestili zunaj mesta, v antičnem Rimu pa je onesnaževanje ozračja urejalo civilno pravo (Jacobson, 2002).

Slovenska mesta niso nobena izjema; prej bi lahko rekli, da zaradi splošne neprevetrenosti in pogostih temperaturnih inverzij izkazujejo večjo občutljivost na obremenjevanje kot nekatera druga evropska ali svetovna mesta. Najbolj tipičen primer je Ljubljana, katere kakovost zraka preučujemo v tem prispevku. Ljubljana je v 20. st. iz deželnega središča postala državno središče. Ta proces je spremljalo zgoščevanje industrije (do 80. let 20. st.), poselitve in upravno-administrativnih funkcij. V obdobju zadnjih dveh desetletij je tako za Ljubljano kot tudi za ostale slovenske pokrajine značilna hitra rast motorizacije in prometnega dela (Lampič, Ogrin, 2009), s tem pa je povezano tudi večje prometno onesnaževanje, ki je postajalo vse pomembnejši dejavnik obremenjevanja ozračja, medtem ko je industrija zaradi deindustrializacije, terciarizacije in tudi prestrukturiranja v bolj zelene tehnologije v Ljubljani od 80. let 20. st. postopno izgubljala vlogo velikega onesnaževalca. V Ljubljani so k onesnaževanju ozračja veliko prispevala tudi individualna kurišča in obe toplarni, vse dokler se je kot glavni energent uporabljalo domač rjavi premog z veliko žvepla in majhno energijsko vrednostjo (Palatinus, 2009).

V 70. letih prejšnjega stoletja se je Ljubljana uvrščala med mesta z najbolj onesnaženim zrakom v Sloveniji (Špes, Lampič, Smrekar, 2000). Glavni problem je bila onesnaženost z žveplovim dioksidom, ki se je v 80. letih prejšnjega stoletja začela hitreje zmanjševati, v drugi polovici 90 . let in v prvih letih po letu 2000 pa so koncentracije po zaslugi zamenjave energentov in uveljavitve daljinskega ogrevanja upadle na raven, ki je daleč od meje ogrožanja (Kušar, Vintar Mally, 2004; Plut, 2007, str. 28-29). S plinifikacijo 
gospodinjstev, prehodom na rabo kurilnega olja, menjavo ekološko spornega in energijsko revnega domačega premoga $\mathrm{z}$ uvoženim ter $\mathrm{z}$ večjo energetsko učinkovitostjo stavb se je sicer rešila težava $\mathrm{s}$ koncentracijami žveplovega dioksida, ne pa tudi z ostalimi onesnaževali. V zadnjih letih je v strukturi energentov zaznati porast rabe biomase, kar ponovno prispeva k nekoliko povečanemu obremenjevanju ozračja, zlasti ker je tehnologija peči v stanovanjskih hišah zastarela. Tako danes k onesnaževanju zraka v Ljubljani prispevajo predvsem promet in proizvodnja toplote $\mathrm{v}$ stanovanjskih stavbah in toplarnah, medtem ko industrija nima večje vloge.

$\mathrm{V}$ mestnem ozračju so izpusti dušikovih oksidov večinoma posledica prometnega onesnaževanja in proizvajanja toplote $\mathrm{v}$ toplarnah, lahko tudi procesov izgorevanja $\mathrm{v}$ termoelektrarnah. V Evropski uniji je bilo leta 2009 47,5 \% izpustov dušikovih oksidov posledica prometa (Sector share ..., 2012). V Sloveniji je ta delež leta 2007 znašal $56 \%$, medtem ko je cestni promet v Sloveniji istega leta povzročil $42 \%$ izpustov dušikovih oksidov (Rode, 2009), leta 2011 pa 54 \% (Kakovost zraka v Sloveniji v letu 2012, 2013). V Mestni občini Ljubljana je pri emisijah dušikovih oksidov po sektorjih na prvem mestu promet s $60 \%$, na drugem mestu pa so pretvorniki energije s $27 \%$ (Cerkvenik, Persovšek, Podboj, 2010). Meritve dušikovega dioksida v gosti merilni mreži v preteklosti so že nakazale problem kakovosti zraka ponekod v Ljubljani (Ogrin, M., 2007; 2008; Ogrin, D. in sod., 2006; Čemas, 2013) in potrdile upravičenost gostejših meritev. Prav tako so raziskave v različnih slovenskih okoljih pokazale, da prebivalci med glavnimi okoljskimi problemi, ki jim znižujejo kakovost bivanja, še vedno najpogosteje izpostavljajo hrup in onesnažen zrak, za oboje pa v največji meri krivijo prav promet (Vintar Mally, 2009). Zaradi tega so preučevanja prometnega obremenjevanja ozračja posebej dragocena za izboljševanje kakovosti bivalnega okolja (mestnega) prebivalstva.

V prispevku bomo primerjali onesnaženost zraka z dušikovim dioksidom v Ljubljani v poletnem času v letih 2005 in 2013 . V letu 2005 so meritve potekale od 25. avgusta do 14. septembra, v letu 2013 pa od 26. avgusta do 16. septembra. Poudarek našega raziskovanja je bil na prometnem onesnaževanju, saj so meritve potekale v različnih tipih mestnega prostora $z$ različno prometno obremenitvijo. Namen primerjave je ugotoviti, ali se prometno onesnaževanje z dušikovim dioksidom spreminja in kako. Glede na vse nižje emisijske standarde vozil bi pričakovali nižje koncentracije, po drugi strani pa se je obseg prometa v tem obdobju še vedno povečeval, kar znižuje pozitiven učinek novejše tehnologije.

Meritve onesnaženosti zraka smo na Oddelku za geografijo Filozofske fakultete Univerze v Ljubljani izvajali v sodelovanju z Agencijo Republike Slovenije za okolje v okviru dveh raziskovalnih projektov. V letu 2005 je bil to projekt z naslovom Prometno onesnaževanje ozračja v Ljubljani znotraj avtocestnega obroča, v letu 2013 pa smo izvajali projekt z naslovom Urban heat island, pri katerem je bil projektni partner tudi Geografski inštitut Antona Melika ZRC SAZU. Posebna zahvala za nesebično strokovno pomoč pri izvajanju meritev gre g. Antonu Planinšku iz Agencije Republike Slovenije za okolje, dr. Darku Ogrinu ter študentom Oddelka za geografijo Filozofske fakultete v Univerze v Ljubljani Valentini Pajk, Petri Udrih, Nejcu Bobovniku in Simonu Koblarju. 


\section{METODE DELA}

Dušikov dioksid sodi v skupino dušikovih oksidov $\left(\mathrm{NO}_{\mathrm{x}}\right)$, ki jo sestavljajo dušikov monoksid (NO), dušikov dioksid $\left(\mathrm{NO}_{2}\right)$ in tudi didušikov oksid $\left(\mathrm{N}_{2} \mathrm{O}\right)$. V povezavi s prometnim onesnaževanjem največkrat mislimo na dušikov monoksid in dušikov dioksid, pri čemer je treba vedeti, da kot produkt izgorevanja v motorjih vozil velika večina dušikovih oksidov pride v ozračje kot dušikov monoksid, ki se potem hitro spremeni v precej obstojnejši dušikov dioksid. Dušikov dioksid je torej lahko primarno ali sekundarno onesnaževalo.

Z vidika ugotavljanja prostorskih vzorcev onesnaženja se je že leta 2005 kot primerna metoda ugotavljanja kakovosti zraka izkazala uporaba difuzivnih vzorčevalnikov, zato smo jo uporabili tudi leta 2013. Poleg dušikovega dioksida lahko s to metodo merimo tudi nekatera druga onesnaževala, kot so ozon, žveplov dioksid in benzen. Metoda temelji na prenosu onesnaževala v vzorčevalniku s pomočjo molekularne difuzije. Difuzivni vzorčevalniki merijo prisotnost določenih snovi v zraku z metodo pasivnega vzorčenja, zato jim pravimo tudi pasivni vzorčevalniki. To pomeni, da za dovajanje zraka vanje ne potrebujemo črpalke, pač pa so izpostavljeni na zraku v zunanjih pogojih. Stopnja vzorčenja je nadzorovana s stopnjo difuzije onesnaževala $v$ zraku znotraj vzorčevalnika, določa pa jo Fickov zakon difuzije, kar pojasni ime vzorčevalnika.

Obstaja več vrst difuzivnih vzorčevalnikov. V raziskavi smo uporabili Palmesove vzorčevalnike, ki se uporabljajo pogosto, odkar so bili leta 1976 prvič preizkušeni in opisani (Palmes in sod., 1976). Gre za 7,1 cm dolgo cevko z notranjim presekom 0,71 $\mathrm{cm}^{2}$, ki ima na zaprtem koncu kovinsko mrežico, premazano s trietanolaminom, ki deluje kot sorbent. Na enem koncu je cevka zaprta, na drugem pa v času meritev odprta. Skozi to odprtino v času vzorčenja vstopa zunanji zrak in s seboj prinaša tudi onesnaževala. Ko onesnaževalo v cevki doseže membrano, se pretvori v nitrit, ki ostane na membrani. Tako je koncentracija dušikovega dioksida $v$ neposredni bližini membrane vedno enaka nič, saj ga sorbent veže nase in spremeni. Zato se v cevki vedno, kadar je koncentracija dušikovega dioksida vstopajočega zraka različna od nič, vzpostavi gradient koncentracije, ki zaradi molekularne difuzije povzroči tok molekul dušikovega dioksida proti membrani z reagentom. Po koncu vzorčenja se vzorčevalnik zapre, membrane pa oddajo v kemijsko analizo, kjer se z ustrezno kemijsko analitsko metodo določi maso in posledično tudi povprečno koncentracijo onesnaževala, v našem primeru dušikovega dioksida.

Metoda merjenja z difuzivnimi vzorčevalniki ima nekaj pomembnih prednosti. Te so:

- Fleksibilnost in praktičnost. Postavljanje je preprosto in hitro, lahko ga opravi ena oseba. Vzorčevalniki in zakloni so lahki, majhni in ob zadovoljivi negi vzdržljivi. V enem dnevu jih lahko postavimo tudi več sto, kar močno poveča kakovost informacije o onesnaženosti zraka.

- Nizka cena. Ta omogoča večji obseg meritev in tako precej podrobnejše prostorske podatke o onesnaženosti, ki so lahko tudi osnova za kartografski prikaz onesnaženosti. Zaradi nizke cene lahko merilna obdobja pogosto ponavljamo, merilna mesta pa izbiramo sproti in lažje prenesemo izgubo vzorčevalnika zaradi vandalizma. 
Slabosti te metode pa so:

- Manjša zanesljivost, ki je ocenjena do 30 \% (Cox, 2003; Bush in sod., 2001), vendar pa so mnenja o zanesljivosti teh meritev zelo različna. Po zagotovilu proizvajalca vzorčevalnikov Gradko International, ki analize tudi izvaja, je natančnost rezultatov analitske metode $\pm 8 \%$. Napake vsakega merilnega obdobja lahko ocenimo in odpravimo z vzporednimi meritvami na referenčnih samodejnih postajah, kjer za čas trajanja meritev ugotovimo razlike med rezultati meritve $\mathrm{z}$ vzorčevalniki in $\mathrm{z}$ avtomatskim merilnikom. Ob predpostavki, da so bili zunanji pogoji vzorčevalnika na referenčni postaji dovolj podobni ostalim v okolici, lahko razmerje med referenčno vrednostjo ter vrednostjo vzorčevalnika uporabimo kot faktor, s katerim korigiramo ostale izmerjene vrednosti.

- S to metodo pridobljeni rezultati dajejo samo informacijo o povprečni onesnaženosti, ne pa tudi o maksimalnih, urnih, nekajurnih oziroma dnevnih vrednostih, na katere se nanašajo mejne vrednosti.

- Metoda tudi ni primerna za spremljanje kakovosti zraka v realnem času, saj so rezultati na razpolago z zamikom šele po končani kemijski analizi vzorčevalnikov, kar lahko traja od nekaj dni do nekaj tednov.

- Merjenje s Palmesovimi difuzivnimi vzorčevalniki je tudi manj primerno za krajše obdobje in mora trajati vsaj nekaj dni, še bolje pa je, da traja od enega do treh tednov. Kjer so koncentracije merjenih onesnaževal nizke, težimo k daljšemu merilnemu obdobju, da je količina nabrane mase onesnaževala na membrani večja od praga zaznavanja $\mathrm{v}$ analitski metodi.

Vzorčevalnike smo v obeh preučevanih poletjih izpostavili v posebnih zaklonih, ki zmanjšajo turbulentnost $\mathrm{v}$ okolici vzorčevalnika in posledično tudi $\mathrm{v}$ njem. To je pomembno, saj vdor turbulence v cevko vzorčevalnika vpliva na difuzijo in kvari kakovost rezultatov. Zaklone smo pritrdili na cestne svetilke, prometne znake, semaforje, hišne žlebove in podobno. Vzorčevalniki ob cestah so bili izpostavljeni na višini okoli tri metre od tal, večinoma $0,5-3,0 \mathrm{~m}$ od roba cestišča, izjemoma tudi več.

Merilna mesta so bila večinoma ob cestah, v parkih, ob ulicah v stanovanjskih soseskah in v območjih za pešce. Merilna mesta ob cestah so imela dve merilni točki, po eno na vsaki strani ceste. S tem smo se izognili vplivu vetra na razporeditev onesnaženosti, saj je ne glede na smer vetra onesnažen zrak s ceste vedno zaznal vsaj en vzorčevalnik. Kot reprezentativno vrednost takih merilnih mest smo uporabili aritmetično sredino rezultatov z obeh merilnih točk. Meritve dušikovega dioksida smo opravljali v nizih s tremi vzorčevalniki v enem zaklonu, kot vrednost koncentracije na vsaki točki pa smo izračunali aritmetično sredino dveh bližnjih koncentracij, pri tem pa izločili tretjo.

\section{I.Tipi mestnega prostora}

Mestni prostor je zelo heterogen, saj se med seboj prepletajo številne dejavnosti in spreminjajo na zelo kratke razdalje. Gostota, razmestitev in vrsta virov onesnaževanja se v mestu zelo razlikujejo, zato je tudi onesnaženost zraka med mestnimi predeli zelo 
različna. Pri ugotavljanju spreminjanja onesnaženosti zraka znotraj mesta je nujno postaviti gosto mrežo merilnih mest v različnih tipih prostora. Merilna mesta smo izbrali glede na tipe mestnega prostora, te pa smo določili že v prvi raziskavi leta 2005:

- Urbano ozadje. Za merilna mesta v urbanem ozadju velja, da na potek koncentracij viri ne vplivajo neposredno, pač pa z zamikom. Dnevna nihanja koncentracij onesnaževal so bistveno manjša kot ob cestah, kjer se kažejo nihanja v prometnih obremenitvah, povprečne koncentracije pa so nižje. Ta mesta so na območjih stanovanjskih sosesk, parkov, vrtičkov in podobnih predelov ter so praviloma bolj oddaljena od večjih cest in drugih virov, ki bi neposredno vplivali na hod koncentracij. Onesnaženost teh območij je pomembna zato, ker se v njih ljudje pogosto in dlje zadržujejo, tam preživljajo prosti čas, tovrstne površine pa med ljudmi nasploh veljajo za mirne in manj onesnažene.

- Cestni koridorji. Cestni koridorji so posebna prostorska kategorija. Gre za utesnjene, gosto pozidane oziroma obzidane površine, navadno v mestnih središčih, kjer se vpadnice stekajo na trge in večja parkirišča ali pa vodijo na glavno cesto, ki poteka skozi mestno središče. V teh koridorjih je promet pogosto zgoščen, njegova hitrost pa zelo majhna. Čeprav imajo navadno manjše prometne obremenitve od mestnih vpadnic na robu mesta ali obvoznic, je prometna zasedenost teh površin visoka. Ker so samočistilne sposobnosti ozračja v koridorjih zelo okrnjene, so koncentracije primarnih onesnaževal večje. Na ozkih površinah v teh koridorjih se pogosto mudijo tudi pešci, bodisi na avtobusnih postajališčih bodisi na površinah za pešce, ne smemo pa pozabiti tudi na potnike $\mathrm{v}$ avtobusih in avtomobilih.

- Merilna mesta v odprtem prostoru ob cestah. Meritve smo izvajali tudi ob vpadnicah in drugih cestah izven koridorjev, da smo dobili vpogled v stanje kakovosti zraka oziroma njegove onesnaženosti z dušikovim dioksidom ob cestah, kjer ne prihaja do zgoščevanj onesnaževal zaradi topografije, onesnaženost pa je odvisna od prometne obremenitve ter od hitrosti prometa po njih.

- Profili koncentracij dušikovega dioksida ob cestah. Merili smo tudi spreminjanje koncentracij v prečni razdalji glede na cesto, ki je glavni vir onesnaževanja. To so t. i. prečni profili koncentracij, ki sicer niso poseben tip prostora. V obeh merilnih obdobjih smo opravili meritve na prečnem profilu Cankarjeve in Čopove ulice v območju za pešce v središču mesta, kjer je glavni vir onesnaženja promet po Slovenski cesti.

\section{VREMENSKE RAZMERE V ČASU MERITEV}

Vremenske razmere lahko pomembno vplivajo na stopnjo onesnaženosti. Ljubljana ima lahko vremenska stanja, ko je ozračje labilno in dinamično, kar je dobro za kakovost zraka, na drugi strani pa se pojavljajo obdobja dolgotrajne stabilnosti (npr. večdnevne zimske inverzije), ko je vpliv vremena na kakovost zraka izrazito negativen. Za poletne vremenske razmere v splošnem velja, da Sončevo obsevanje ob sončnih dneh brez težav termično razkroji plitve inverzije, ki se nad Ljubljano pojavijo v jasnih nočeh. Ob prehodih vremenskih front in ciklonov pa za nižje koncentracije onesnaževal poskrbijo vetrovi in padavine. Vseeno pa se lahko tudi poleti pojavijo za kakovost zraka manj in bolj ugodna vremenska stanja. Dolgotrajna sušna obdobja brez vetrov in padavin so bolj 
problematična kot obdobja pogostih prehodov vremenskih front ter menjavanja sončnega in padavinskega vremena. Čeprav spada Ljubljana med skromno prevetrena mesta, se lahko ob prehodih front ali ob bližini ciklonov pojavi nekajdnevno vetrovno vreme, ki poveča samočistilne sposobnosti ozračja.

Preglednica 1: Pogostnost vetra v času poletnih meritev leta 2005 in 2013 na meteorološki postaji Ljubljana-Bežigrad (v\%)

Table 1: Wind frequency during the measurements in the summers of 2005 and 2013 at the weather station Ljubljana-Bežigrad (in \%)

\begin{tabular}{|l|c|c|c|c|c|c|c|c|}
\hline & S & SV & V & JV & J & JZ & Z & SZ \\
\hline $\mathbf{2 0 0 5}$ & 16,0 & 24,8 & 15,9 & 9,7 & 7,6 & 16,4 & 4,9 & 4,6 \\
\hline $\mathbf{2 0 1 3}$ & 18,6 & 18,8 & 12,3 & 15,7 & 9,7 & 13,8 & 5,3 & 5,9 \\
\hline
\end{tabular}

Vir/Source: Arhiv ARSO, 2013

Preglednica 2: Povprečna hitrost vetra v času poletnih meritev leta 2005 in 2013 na meteorološki postaji Ljubljana-Bežigrad ( $\mathrm{v} \mathrm{m} / \mathrm{s}$ )

Table 2: Average wind speed during the measurements in the summers of 2005 and 2013 at the weather station Ljubljana-Bežigrad (in $\mathrm{m} / \mathrm{s}$ )

\begin{tabular}{|l|c|c|c|c|c|c|c|c|}
\hline & $\mathbf{S}$ & $\mathbf{S V}$ & $\mathbf{V}$ & $\mathbf{J V}$ & $\mathbf{J}$ & $\mathbf{J Z}$ & $\mathbf{Z}$ & $\mathbf{S Z}$ \\
\hline $\mathbf{2 0 0 5}$ & 0,8 & 0,8 & 1,1 & 1,1 & 1,3 & 2,1 & 1,3 & 1,0 \\
\hline $\mathbf{2 0 1 3}$ & 1,1 & 1,1 & 1,4 & 1,4 & 1,4 & 1,4 & 0,8 & 1,2 \\
\hline
\end{tabular}

Vir/Source: Arhiv ARSO, 2013

Preglednica 1 kaže, da je bila pogostnost vetrov glede na smer na meteorološki postaji Ljubljana-Bežigrad v primerjanih obdobjih precej podobna pri večini vetrov, bistveno manj je leta 2013 pihal le severovzhodnik, nekoliko manj vzhodnik, opazno več pa je bilo jugovzhodnika. A bolj kot razlika pri pogostnosti smeri je pomembna hitrost vetra (preglednica 2). Pri vseh smereh, razen pri jugozahodniku in zahodniku, je bila povprečna hitrost leta 2013 višja, kar pomeni, da je leta 2005 le okoli 20 \% časa meritev veter pihal močneje kot med meritvami leta 2013. Torej smo imeli poleti 2005 manjšo prevetrenost in manjše samočistilne sposobnosti ozračja.

Med meritvami v letu 2005 so bile temperature nekoliko višje kot leta 2013. Srednja dnevna temperatura $\mathrm{v}$ Ljubljani med poletnim merilnim obdobjem leta 2005 je bila $18,7{ }^{\circ} \mathrm{C}$, leta 2013 pa $17,4{ }^{\circ} \mathrm{C}$. Najvišja dnevna temperatura je bila leta $200528,6{ }^{\circ} \mathrm{C}$, najnižja pa $11,1^{\circ} \mathrm{C}$, medtem ko je bila leta 2013 najvišja dnevna temperatura $29,2{ }^{\circ} \mathrm{C}$, najnižja pa $8,7^{\circ} \mathrm{C}$ (Arhiv ARSO, 2013). Tako majhne temperaturne razlike same po sebi ne vplivajo na kakovost zraka, pač pa imajo večji vpliv vetrovnost ter pogostnost in količina padavin.

Leta 2005 je padlo v Ljubljani v celotnem obdobju meritev 132,3 mm padavin v sedmih padavinskih dneh (dnevi, ko je padlo več kot $1 \mathrm{~mm}$ padavin), leta 2013 pa 
178,8 mm v dvanajstih padavinskih dneh (Arhiv ARSO, 2013), kar nakazuje večje izpiranje onesnaževal iz ozračja med poletnim merilnim obdobjem 2013. Ugotavljamo, da so bile med meritvami leta 2013 samočistilne sposobnosti ozračja v Ljubljani nekoliko boljše kot leta 2005 .

\section{OBREMENJEVANJE OZRAČJAV LJUBLJANI}

Za onesnaženost ozračja nekega območja je obremenjevanje prav tako pomemben dejavnik kot meteorološko stanje ozračja. $\mathrm{V}$ tem poglavju bomo navedli nekaj podatkov o izpustih in prometnih obremenitvah v preučevanem obdobju.

Energetska bilanca Mestne občine Ljubljana (Cerkvenik, Persovšek, Podboj, 2010, str. 39) navaja zmanjšanje izpustov dušikovih oksidov od leta 2006 do leta 2009 za 7,7 \%. Razloga naj bi bila vse čistejša tehnologija vozil in zmanjšanje tranzitnega prometa zaradi gospodarske krize. Emisije dušikovih oksidov iz prometa v Mestni občini Ljubljana so v obdobju 2005-2008 po ocenah padle za 3,3 \%. Leta 2008 naj bi v mestni občini promet prispeval $56 \%$ vseh dušikovih oksidov, ta delež pa se v obdobju 2000-2008 ni bistveno spreminjal in je bil med 52 in 56 \% (Cerkvenik, 2010). Novejših podatkov o izpustih nimamo, a dejstvo je, da se delež vozil z novejšimi emisijskimi standardi (EURO 4 in mlajši) povečuje, kar zagotovo zmanjšuje izpuste dušikovih oksidov.

Preglednica 3: Povprečni letni dnevni promet na odsekih ljubljanske obvoznice v obdobju 2005-2012

Table 3: Annual average daily traffic on Ljubljana ring road sections in the period 2005-2012

\begin{tabular}{|l|c|c|c|c|}
\hline Leto (PLDP) & $\begin{array}{c}\text { Vzhodna } \\
\text { obvoznica }\end{array}$ & $\begin{array}{c}\text { Južna } \\
\text { obvoznica }\end{array}$ & $\begin{array}{c}\text { Zahodna } \\
\text { obvoznica }\end{array}$ & $\begin{array}{c}\text { Severna } \\
\text { obvoznica }\end{array}$ \\
\hline 2005 & 52.847 & 52.069 & 55.193 & 57.685 \\
\hline 2006 & 55.111 & 53.961 & 59.723 & 59.468 \\
\hline 2007 & 57.358 & 56.476 & 63.970 & 60.398 \\
\hline 2008 & 60.026 & 59.992 & 67.568 & 61.274 \\
\hline 2009 & 61.009 & 63.105 & 71.691 & 65.196 \\
\hline 2010 & 62.209 & 64.150 & 71.546 & 64.192 \\
\hline 2011 & 63.077 & 66.026 & 72.801 & 65.388 \\
\hline Indeks rasti 2012/2005 & 61.335 & 64.050 & 68.587 & 59.847 \\
\hline
\end{tabular}

Vir/Source: Arhiv podatkov o prometnih obremenitvah, 2013

Preglednica 3 kaže, da je prometna obremenitev na ljubljanski obvoznici od leta 2005 do 2012 narasla za 4-24 \%. Sicer se kaže manjše zmanjšanje prometa v letu 2012 glede na prejšnja leta, a je količina prometa še vedno večja kot leta 2005, kar je v 
nasprotju s trditvami iz energetske bilance o obsegu prometnih obremenitev (Cerkvenik, Persovšek, Podboj, 2010, str. 39).

Preglednica 4: Število priklopnikov, vlačilcev in tovornjakov s skupno maso nad 7 ton na ljubljanski obvoznici v obdobju 2005-2012

Table 4: Number of trailers, towing vehicles, and trucks with a total mass of more than 7 tons on the Ljubljana ring road in the period 2005-2012

\begin{tabular}{|l|c|c|c|c|c|}
\hline Leto (PLDP) & $\begin{array}{c}\text { Vzhodna } \\
\text { obvoznica }\end{array}$ & $\begin{array}{c}\text { Južna } \\
\text { obvoznica }\end{array}$ & $\begin{array}{c}\text { Zahodna } \\
\text { obvoznica }\end{array}$ & $\begin{array}{c}\text { Severna } \\
\text { obvoznica }\end{array}$ & $\begin{array}{c}\text { Vse } \\
\text { obvoznice } \\
\text { skupaj }\end{array}$ \\
\hline 2005 & 3116 & 3778 & 3044 & 2559 & 12.497 \\
\hline 2006 & 3524 & 4411 & 3288 & 2478 & 13.701 \\
\hline 2007 & 3978 & 4885 & 4050 & 3273 & 16.186 \\
\hline 2008 & 4336 & 5352 & 4456 & 3492 & 17.636 \\
\hline 2009 & 3819 & 4568 & 4193 & 3593 & 16.173 \\
\hline 2010 & 3693 & 4450 & 4126 & 3540 & 15.809 \\
\hline 2011 & 3639 & 4412 & 4210 & 3638 & 15.899 \\
\hline 2012 & 4151 & 4875 & 3528 & 2756 & 15.310 \\
\hline Indeks rasti 2012/2005 & 133 & 129 & 116 & 108 & 123 \\
\hline
\end{tabular}

Vir/Source: Arhiv podatkov o prometnih obremenitvah, 2013

Iz preglednice 4 lahko razberemo trende v obsegu tovornega prometa na ljubljanski obvoznici. Opazen je porast v obdobju 2005-2008, ki mu je v naslednjih dveh letih sledil padec. V letu 2011 je bil promet omenjenih tovornih kategorij v celoti gledano spet zelo podoben letu 2010, leta 2012 pa je bil skupen obseg prometa za $4 \%$ nižji kot leto prej. Promet na vseh odsekih skupaj nam pokaže sliko celotne obremenjenosti in izniči razbremenitev enega odseka na račun drugega. V primerjavi z letom 2005 se je torej tudi cestni tovorni promet na ljubljanski obvoznici povečal za 8 do $33 \%$, kar je še nekoliko več od rasti osebnega prometa in tudi ne potrjuje trditve energetske bilance o zmanjšanju tranzitnega prometa mimo Ljubljane (Cerkvenik, Persovšek, Podboj, 2010, str. 39). Res pa je, da so začeli prometni tokovi leta 2009 rahlo upadati.

Preglednici 3 in 4 nakazujeta splošno sliko obsega prometa okoli Ljubljane in tudi v samem mestu v obdobju 2005-2012, saj se velik del prometa z obvoznice usmeri tudi v mesto. Ne odsevajo pa ti podatki prometa skozi posamezne dele mesta, a vseeno kažejo, da so se v tem obdobju nekoliko povečali tudi splošni prometni tokovi v mesto. To samo po sebi povečuje izpuste, če se starost in tehnologija voznega parka ter s tem tehnologija izpušnih sistemov ne spremenita.

K nižjim prometnim obremenitvam gre dodati še postopno prenovo voznega parka Ljubljanskega potniškega prometa. V letu 2011 je imelo že 52 \% njegovih vozil vgrajen emisijski standard EURO 3 ali mlajšega (Dovečar, Ogrin, 2011), kar zagotovo pripomore $\mathrm{k}$ manjšim izpustom kot pred leti. 


\section{REZULTATI MERITEV}

V nadaljevanju prispevka predstavljamo rezultate poletnih meritev v letu 2013 in primerjavo z meritvami iz poletja 2005. Meritve so potekale v podobnih terminih in so obakrat trajale tri tedne, in sicer v letu 2005 od 25. avgusta do 14. septembra, v letu 2013 pa od 26. avgusta do 16. septembra. V obeh obdobjih smo izvedli še bistveno več meritev v posameznih tipih mestnega prostora, a merilna mesta so bila na istih lokacijah le v spodaj navedenih primerih. Meritve smo primerjali z zakonsko določenimi vrednostmi, čeprav mejne vrednosti za teden ali nekaj tednov niso določene. Za dušikov dioksid so zakonsko določene naslednje mejne vrednosti (Kakovost zraka v Sloveniji v letu 2012, 2013):

- mejna letna koncentracija za varovanje zdravja znaša $40 \mu \mathrm{g} / \mathrm{m}^{3}$;

- mejna urna vrednost za varovanje zdravja znaša $200 \mu \mathrm{g} / \mathrm{m}^{3}$;

- alarmna triurna koncentracija za varovanje zdravja znaša $400 \mu \mathrm{g} / \mathrm{m}^{3}$.

Glede na potek meritev je izmerjene vrednosti, ki so v bistvu povprečne tritedenske koncentracije, najbolj smiselno primerjati z mejno letno koncentracijo za varovanje zdravja.

Preglednica 5: Koncentracije dušikovega dioksida v Ljubljani v poletnih merilnih obdobjih leta 2005 in 2013 v cestnem koridorju Slovenske in Poljanske ceste $\left(v \mu \mathrm{g} / \mathrm{m}^{3}\right)$

Table 5: Nitrogen dioxide concentrations in Ljubljana during the summer measuring campaigns of 2005 and 2013 in the street canyons of Slovenian and Poljane Street (in $\mu \mathrm{g} / \mathrm{m}^{3}$ )

\begin{tabular}{|l|c|c|c|}
\hline Merilno mesto & Poletje 2005 & Poletje 2013 & $\begin{array}{c}\text { Absolutna in relativna razlika } \\
\mathbf{2 0 1 3 / 2 0 0 5}\left(\mathbf{v} \boldsymbol{\mu g} / \mathbf{m}^{\mathbf{3}} \text { in } \mathbf{\%}\right)\end{array}$ \\
\hline Slovenska cesta: Nama & 83 & 72 & $-11(-13 \%)$ \\
\hline Slovenska cesta: Abanka & 79 & $60 *$ & $/$ \\
\hline Slovenska cesta: Bavarski dvor & 70 & 60 & $-10(-14 \%)$ \\
\hline Slovenska cesta: Filozofska fakulteta & 62 & 52 & $-10(-16 \%)$ \\
\hline Slovenska cesta: Figovec & 64 & 51 & $-13(-20 \%)$ \\
\hline Poljanska cesta: Peglezen & 80 & 49 & $-4(-8 \% \%)$ \\
\hline Slovenska cesta: Kongresni trg & 51 & 47 & \\
\hline
\end{tabular}

Opomba: *Le ena merilna točka

Na merilnih mestih v cestnih koridorjih se je koncentracija dušikovega dioksida v letu 2013 glede na leto 2005 v vseh primerih opazno znižala. Na petih merilnih mestih je padec znašal od 8 do 16 \%, na leta 2005 najbolj onesnaženem merilnem mestu na Poljanski cesti pa kar $39 \%$. A še vedno vse vrednosti presegajo $40 \mu \mathrm{g} / \mathrm{m}^{3}$, kar je določena mejna letna vrednost za dušikov dioksid. Poleti 2005 je bila najvišja koncentracija na Poljanski cesti, leta 2013 pa pri veleblagovnici Nama na Slovenski cesti. V obeh primerih je bil zrak najmanj onesnažen z dušikovim dioksidom na Kongresnem trgu, kar pojasnimo z dejstvom, da tam niti ne gre za pravi cestni koridor, saj Slovenska cesta na vzhodni strani prehaja v Kongresni trg. 
Slika 1: Montaža vzorčevalnikov ni zahtevna, vseeno pa terja pazljivost-merilno mesto cestnega koridorja Slovenske ceste v bližini Abanke, kjer so bili vzorčevalniki ukradeni (foto: V. Pajk) Figure 1: The installation of samplers is not difficult, however, it demands careful treatmentmeasuring spot in the street canyon of Slovenian Street near Abanka, where samplers have been stolen (photo: V. Pajk)

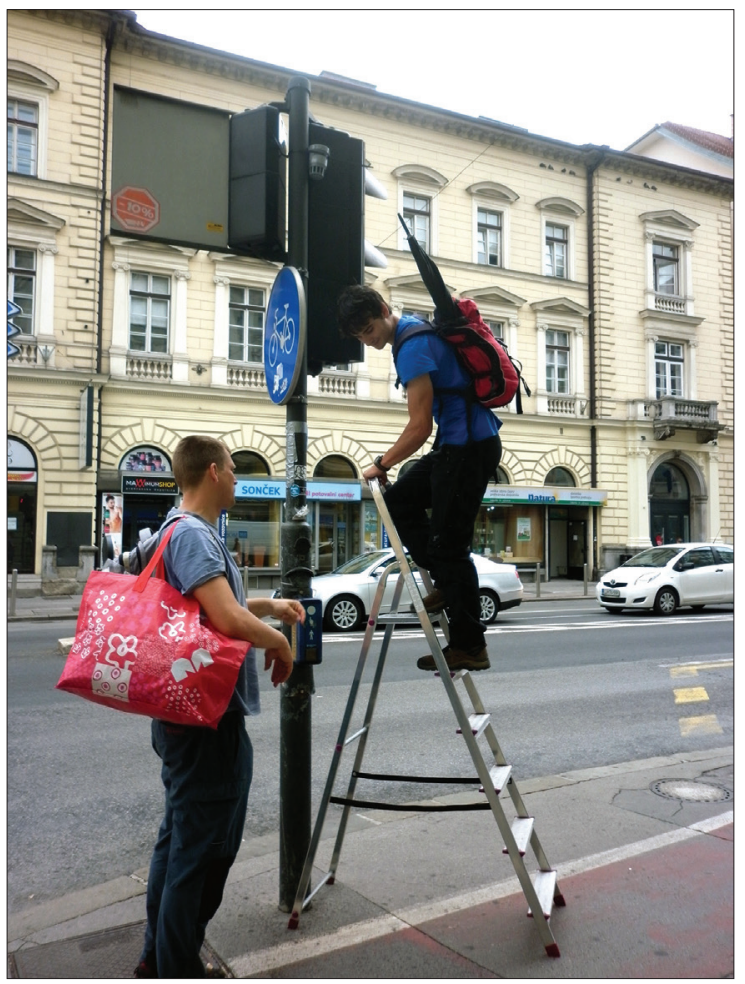

Preglednica 6: Koncentracije dušikovega dioksida v Ljubljani v poletnih merilnih obdobjih leta 2005 in 2013 na odprtem prostoru ob cestah $\left(\mathrm{v} \mathrm{\mu g} / \mathrm{m}^{3}\right)$

Table 6: Nitrogen dioxide concentrations in Ljubljana during the summer measuring campaigns of 2005 and 2013 in open space near the roads (in $\mu \mathrm{g} / \mathrm{m}^{3}$ )

\begin{tabular}{|l|c|c|c|}
\hline Merilno mesto & Poletje 2005 & Poletje 2013 & $\begin{array}{c}\text { Absolutna in relativna razlika } \\
\mathbf{2 0 1 3} / \mathbf{2 0 0 5}\left(\mathbf{v} \boldsymbol{\mu g} / \mathbf{m}^{\mathbf{3}} \text { in \%) }\right.\end{array}$ \\
\hline Trg OF: avtobusna postaja & 59 & 54 & $-5(-8 \%)$ \\
\hline $\begin{array}{l}\text { Dunajska cesta: Gospodarsko } \\
\text { razstavišče }\end{array}$ & 46 & 51 & $5(11 \%)$ \\
\hline Celovška cesta: Tivoli & 62 & $40^{*}$ & $/$ \\
\hline
\end{tabular}

Opomba: *Merjeno le na zahodni strani 
Poleti 2005 smo opravljali meritve na odprtem prostoru ob cestah v okrnjenem obsegu, zato lahko opravimo primerjavo le na treh lokacijah, pri čemer imamo za merilno mesto na Celovški cesti pri Tivoliju v letu 2013 na voljo le meritve za en zaklon, saj je bil drugi ukraden. Na glavni avtobusni postaji smo leta 2013 glede na leto 2005 zabeležili 8-odstotni upad, a še vedno je bila koncentracija dušikovega dioksida $54 \mu \mathrm{g} / \mathrm{m}^{3}$, pri Gospodarskem razstavišču pa je bila koncentracija leta 2013 za 11 \% višja. Pri slednjem je treba opozoriti, da je bilo leta 2013 merilno mesto na avtobusnem postajališču, leta 2005 pa ob cesti pri podvozu, zato je verjetno treba razlog za večjo koncentracijo leta 2013 iskati v legi merilnega mesta na avtobusnem postajališču. Za merilno mesto ob Tivoliju na Celovški cesti (pri pivovarni Union) imamo na voljo le eno povprečno vrednost, in sicer na zahodni strani, zato je primerjava z letom 2005 delno neustrezna.

Za onesnaženost zraka v urbanem ozadju lahko ugotovimo, da je v letu 2013 dosegalo bistveno nižje vrednosti kot leta 2005 na treh od petih merilnih mest, medtem ko na enem beležimo 4-odstotni upad, na merilnem mestu ARSO pa celo 10-odstotni porast, vendar gre $\mathrm{v}$ obeh merilnih obdobjih za eno najmanj onesnaženih mest $\mathrm{v}$ tej skupini. Največji upad, kar za eno četrtino, smo izmerili v Mostah, podobno je tudi v Rožni dolini in za Bežigradom. Nasploh je bila v letu 2013 koncentracija dušikovega dioksida na merilnih

Slika 2: Merilno mesto ob Celovški cesti. Vpadnice niso le najhitrejše ceste do središča mesta, predstavljajo tudi pomembne linijske vire onesnaževanja (foto: K. Vintar Mally)

Figure 2: Measuring spot along Celovec Street. Main roads entering the city centre are not only the fastest roads but also important linear pollution sources (photo: K. Vintar Mally)

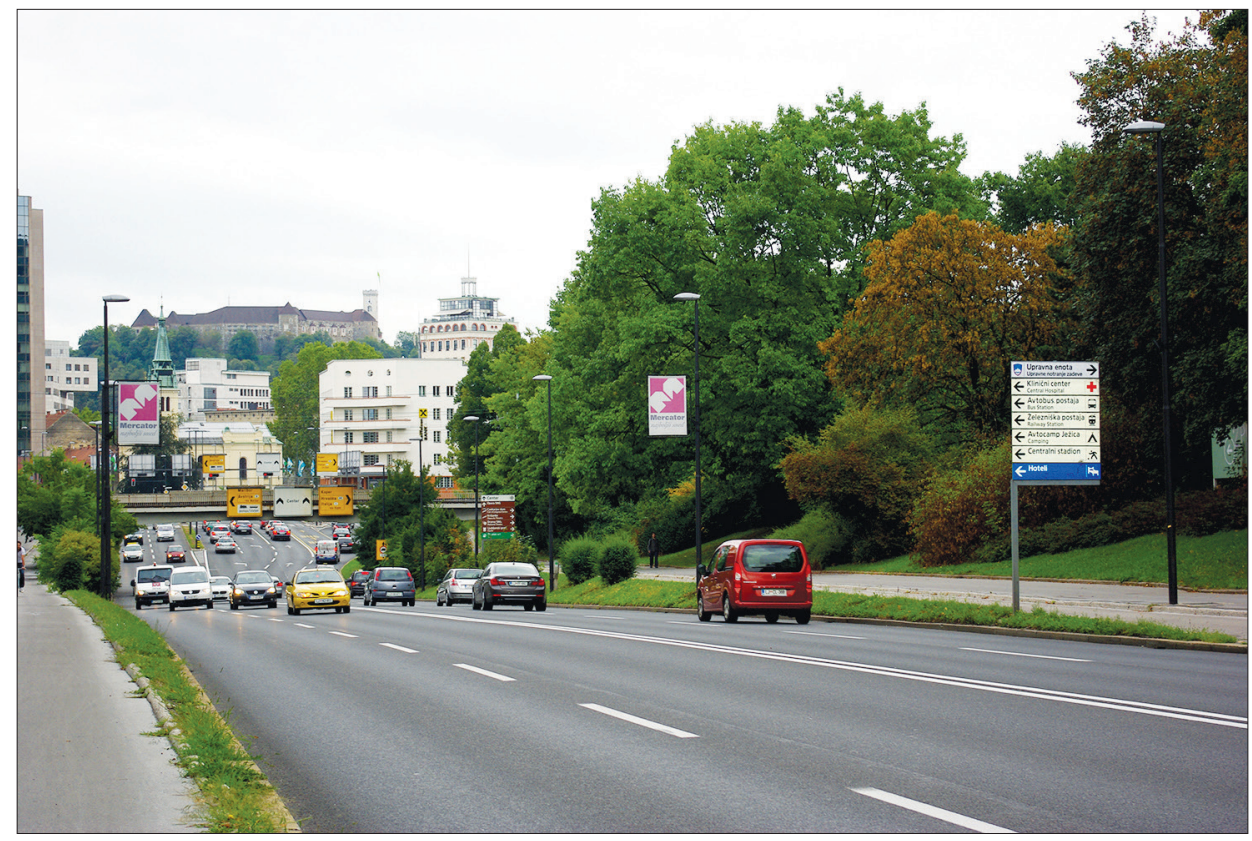


mestih v preglednici 7 zelo podobna (od 22 do $25 \mu \mathrm{g} / \mathrm{m}^{3}$ ), medtem ko je bil razpon koncentracij na istih lokacijah leta 2005 večji (od 21 do $\left.32 \mu \mathrm{g} / \mathrm{m}^{3}\right)$.

Preglednica 7: Koncentracije dušikovega dioksida v Ljubljani v poletnih merilnih obdobjih leta 2005 in 2013 v urbanem ozadju $\left(\mathrm{v} \mu \mathrm{g} / \mathrm{m}^{3}\right)$

Table 7: Nitrogen dioxide concentrations in Ljubljana during the summer measuring campaigns of 2005 and 2013 in urban background (in $\mu \mathrm{g} / \mathrm{m}^{3}$ )

\begin{tabular}{|l|c|c|c|}
\hline Merilno mesto & Poletje 2005 & Poletje 2013 & $\begin{array}{c}\text { Absolutna in relativna razlika } \\
\mathbf{2 0 1 3} / \mathbf{2 0 0 5}\left(\mathbf{v} \boldsymbol{\mu g} / \mathbf{m}^{\mathbf{3}} \text { in \%) }\right.\end{array}$ \\
\hline Šiška: Smrekarjeva ulica & 26 & 25 & $-1(-4 \%)$ \\
\hline Moste: Rojčeva ulica & 32 & 24 & $-8(-25 \%)$ \\
\hline Rožna dolina: Rutarjeva ulica & 30 & 23 & $-7(-23 \%)$ \\
\hline ARSO: Vojkova ulica & 21 & 23 & $2(10 \%)$ \\
\hline Bežigrad: Ptujska ulica & 28 & 22 & $-6(-21 \%)$ \\
\hline
\end{tabular}

Slika 3: Merilno mesto urbanega ozadja na Rutarjevi ulici (foto: K. Vintar Mally

Figure 3: Urban background measuring spot on Rutar Street (photo: K. Vintar Mally)

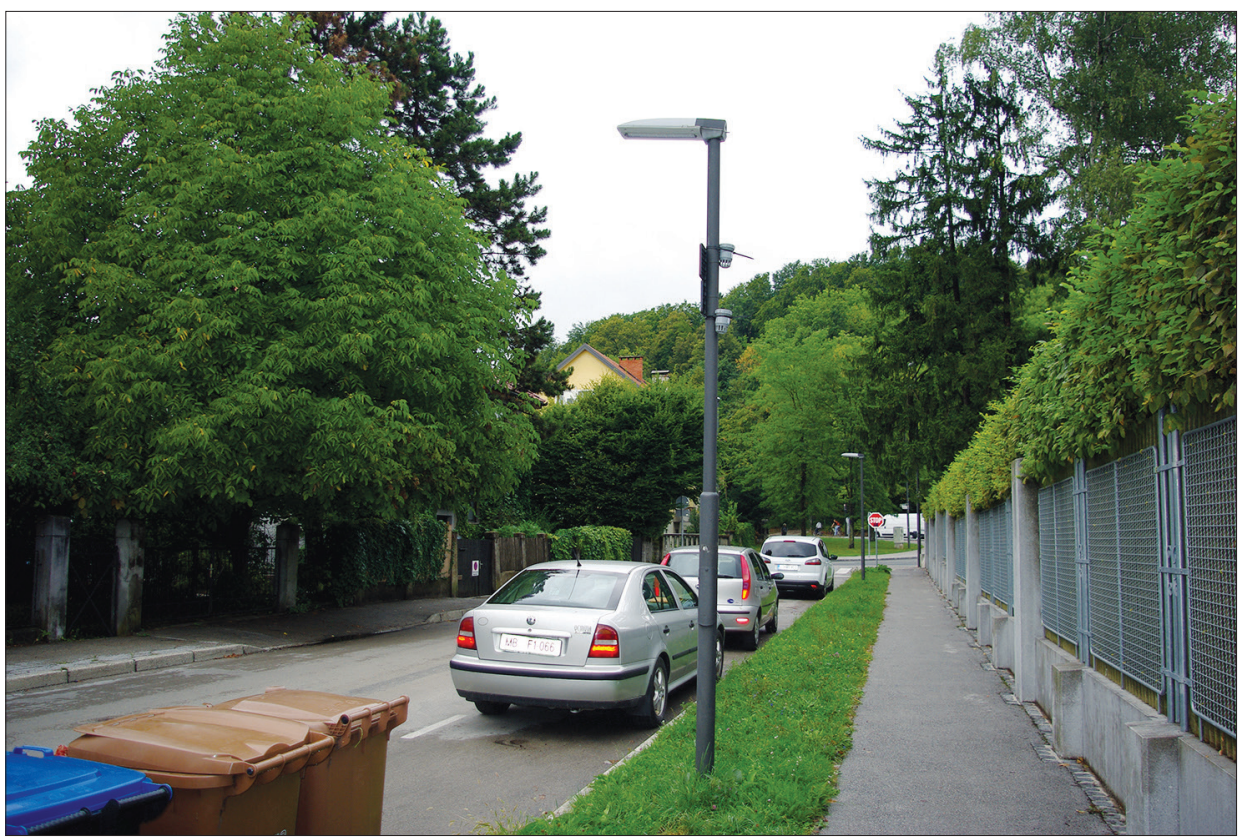


Preglednica 8: Koncentracije dušikovega dioksida v prečnem profilu Čopove in Cankarjeve ulice v Ljubljani v poletnih merilnih obdobjih leta 2005 in $2013\left(v \mu \mathrm{g} / \mathrm{m}^{3}\right)$

Table 8: Nitrogen dioxide concentrations profile on Čop and Cankar Street in Ljubljana during the summer measuring campaigns of 2005 and 2013 (in $\left.\mu \mathrm{g} / \mathrm{m}^{3}\right)$

\begin{tabular}{|l|r|r|r|r|r|r|r|r|r|r|r|}
\hline \multicolumn{5}{|c|}{ Cankarjeva ulica } & \multicolumn{5}{|c|}{ Čopova ulica } \\
\hline $\begin{array}{l}\text { Razdalja od Slovenske } \\
\text { ceste }(\mathrm{m})\end{array}$ & 178 & 130 & 86 & 55 & 0,9 & 0 & 0,9 & 37 & 70 & 154 & 216 \\
\hline $\begin{array}{l}\text { Koncentracije } \mathrm{NO}_{2} \\
\text { v letu 2013 }\end{array}$ & 31 & 32 & 36 & 48 & 76 & & 67 & 33 & 28 & 27 & 25 \\
\hline $\begin{array}{l}\text { Koncentracije } \mathrm{NO}_{2} \\
\text { v letu 2005 }\end{array}$ & 34 & 42 & 48 & 68 & & 79 & 55 & 39 & 38 & \\
\hline
\end{tabular}

Slika 4: Koncentracije dušikovega dioksida v prečnem profilu Čopove in Cankarjeve ulice v Ljubljani v poletnih merilnih obdobjih leta 2005 in $2013\left(\mu \mathrm{g} / \mathrm{m}^{3}\right)$

Figure 4: Nitrogen dioxide concentrations profile on Cop and Cankar Street in Ljubljana during the summer measuring campaigns of 2005 and 2013 (in $\mu \mathrm{g} / \mathrm{m}^{3}$ )

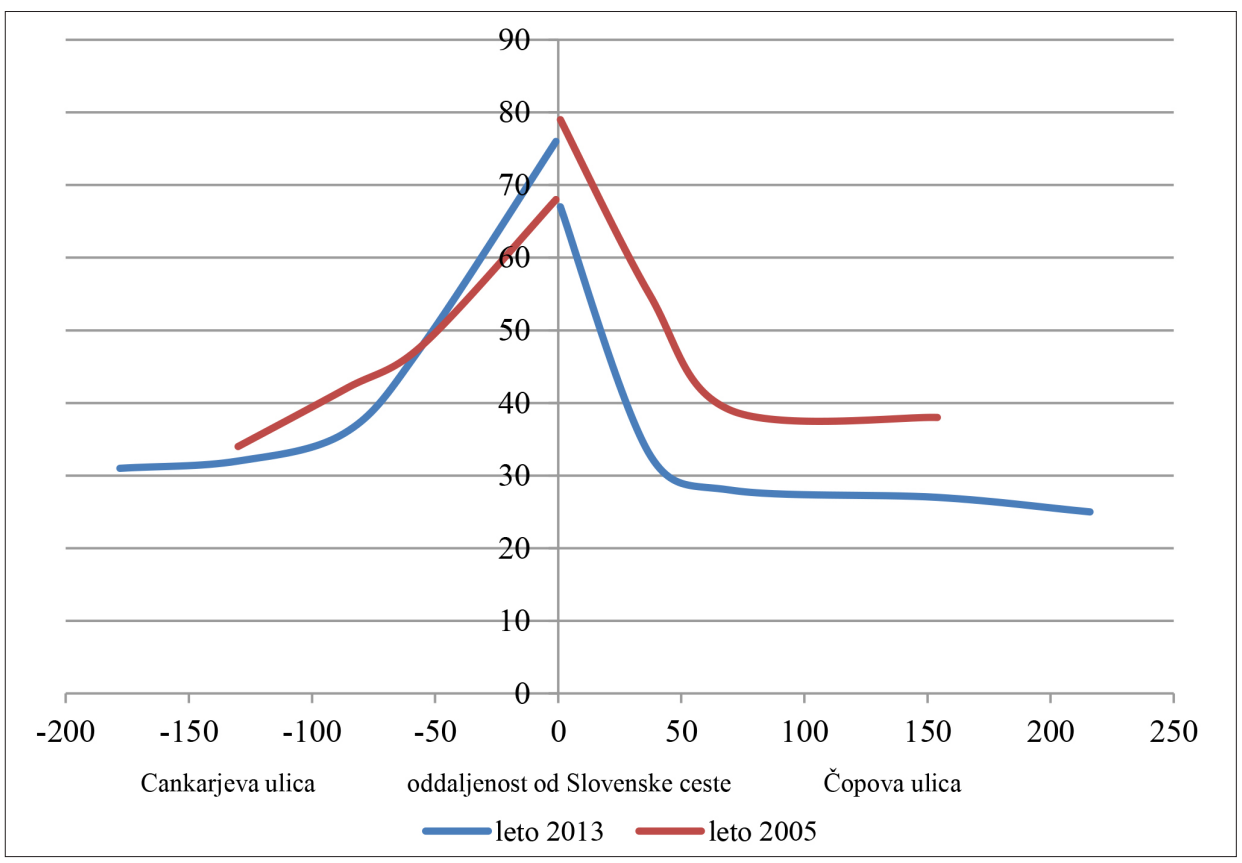

V obeh poletnih merilnih obdobjih smo izmerili podoben potek koncentracij na Cankarjevi in Čopovi ulici, ki potekata pravokotno na Slovensko cesto, kjer je glavni vir dušikovega dioksida. Neposredno ob Slovenski cesti smo izmerili koncentracije med 67 in $79 \mu \mathrm{g} / \mathrm{m}^{3}$ na obeh straneh ceste, na razdalji okoli 70-90 m od Slovenske ceste pa so na Cankarjevi ulici padle pod $40 \mu \mathrm{g} / \mathrm{m}^{3}$, kar je mejna letna koncentracija za dušikov 
dioksid, na Čopovi ulici pa se je to zgodilo prej, že na oddaljenosti okoli 30-70 m. Zanimivo je, da sta bila seštevka koncentracij oziroma aritmetični sredini koncentracij tik ob cesti $v$ obeh poletnih merilnih obdobjih praktično enaki, upad koncentracij po Cankarjevi ulici z oddaljevanjem od Slovenske ceste pa tudi v obeh primerih manjši. To je posledica prometa, ki poteka po tej ulici od križišča z Beethovnovo ulico. Oba profila tudi potrjujeta dejstvo, da je v bližini Slovenske ceste zrak preveč onesnažen, da bi se ljudje v njem zadrževali dlje časa, kar postavlja pod vprašaj umestitev lokalov in trgovin $\mathrm{v}$ to območje.

\section{SKLEP}

Primerjava meritev dušikovega dioksida poleti 2005 in 2013 kaže na splošno znižanje koncentracij. To se je pokazalo v vseh tipih mestnega prostora, čeprav smo za odprt prostor ob cestah izvedli primerjavo le na dveh merilnih mestih in enem pogojno, ker meritev ni bila popolna. V urbanem ozadju smo med seboj primerjali pet merilnih mest in tu se je pri treh prav tako pokazal opazen upad koncentracij, na enem majhen upad in na drugem majhen porast $\left(2 \mu \mathrm{g} / \mathrm{m}^{3}\right.$ oz. $10 \%$ ). V cestnem koridorju smo primerjali sedem merilnih mest, od tega enega pogojno, saj tam meritev ni bila popolna. Zmanjšanje koncentracij se kaže na vseh merilnih mestih in znaša 4-39 \%, kar je razveseljivo, težava pa je, da so vse koncentracije še vedno kar precej nad dovoljeno letno vrednostjo $40 \mu \mathrm{g} / \mathrm{m}^{3}$. Profil koncentracij dušikovega dioksida, ki smo ga izmerili od Slovenske ceste pri veleblagovnici Nama na vsako stran po Cankarjevi in Čopovi ulici, je v obeh meritvah pokazal podoben hod koncentracij in podobne vrednosti tik ob cesti, medtem ko je bilo znižanje koncentracij v letu 2013 hitrejše.

Glede na visoke začetne koncentracije še vedno velja, da je nekaj 10-metrski pas ob Slovenski cesti vzdolž obeh ulic neprimeren za tamkajšnje lokale in trgovine. Padec koncentracij po Čopovi ulici je hitrejši kot po Cankarjevi ulici. V primeru Čopove ulice je bil pas preveč onesnaženega zraka dolg 30-70 m, na Cankarjevi ulici pa kar 70-90 m. Menimo, da je padec koncentracij glede na leto 2005 na večini primerjanih mest posledica dveh dejavnikov: večje dinamike v ozračju in s tem večjih samočistilnih sposobnosti ozračja ter čistejšega voznega parka. Po koncu poletnega merilnega obdobja 2013 so Slovensko cesto od križišča z Gosposvetsko cesto do križišča s Šubičevo cesto zaprli za individualni motorni promet, po njej je dovoljen le javni promet in dostava ter intervencija. Koliko bo upad prometa prispeval k izboljšanju razmer, ne le vzdolž obeh ulic omenjenega prečnega profila, pač pa tudi po tem odseku Slovenske ceste, pa bodo pokazale prihodnje meritve. 


\section{Viri in literatura}

Arhiv ARSO, 2013.

Povprečni letni dnevni promet (PLDP) za pretekla leta. 2013. Direkcija RS za ceste, arhiv podatkov o prometnih obremenitvah. URL: http://www.promet.si/portal/sl/podatki-o-prometnih-obremenitvah.aspx (Citirano 27. 11. 2013).

Bush, T., Smith, S., Stevenson, K., Moorcroft, S., 2001. Validation of nitrogen dioxide diffusion tube methodology in the UK. Atmospheric environment, 35, 2, str. 289-296.

Cerkvenik, B., Persovšek, N., Podboj, A., 2010. Energetska bilanca Mestne občine Ljubljana v letu 2009 in izračun emisij škodljivih snovi. Končno poročilo. Ljubljana, Inštitut za energetiko Energis, 86 str.

Cerkvenik, B., 2010. Ocena in analiza emisij iz prometa na območju MOL. URL: http:// www.civitasljubljana.si/uploads/datoteke/10\%20MOL\%20delavnica\%20promet $\% 20$ IEE.ppt (Citirano 27. 11. 2013).

Cox, M. R., 2003. The use of passive sampling to monitor forest exposure to $\mathrm{O}_{3}, \mathrm{NO}_{2}$ and $\mathrm{SO}_{2}$ : a review and some case studies. Environmental pollution, 126, 3, str. 301-311.

Dovečar, M., Ogrin, M., 2011. Identifikacija stanja javnega potniškega prometa in ukrepov trajnostne mobilnosti v slovenskih občinah. Končno poročilo. Ljubljana, CIPRA Slovenija, 68 str. URL: http://www.cipra.org/sl/CIPRA/cipra-slovenija/ publikacije-1/identifikacija-stanja-javnega-potniskega-prometa-in-ukrepov-trajnostne-mobilnosti-v-slovenskih-obcinah/131213-porocilo-2011_www.pdf (Citirano 25. 11. 2013).

Čemas, D., 2013. Preliminarno poročilo projektov AIRPECO in PEOPLE. Ljubljana, Ministrstvo za okolje in prostor, ARSO, 8 str. URL: http://www.arso.gov.si/zrak/kakovost\%20zraka/poro\%C4\%8Dila\%20in\%20publikacije/AIRPECOinPEOPLEporocilo.pdf (Citirano 5. 12. 2013).

Jacobson, M. Z., 2002. Atmospheric pollution: history, science, and regulation. Cambridge, Cambridge University press, 399 str.

Kakovost zraka v Sloveniji v letu 2012. 2013. Ljubljana, ARSO, 141 str. URL: http:// www.arso.gov.si/zrak/kakovost\%20zraka/poro\%C4\%8Dila\%20in\%20publikacije/ KAKOVOST\%20ZRAKA\%202012.pdf (Citirano 5. 12. 2013).

Kušar, S., Vintar Mally, K., 2004. Ljubljanska urbana regija - problemska regija? Dela, 22 , str. 15-26.

Lampič, B., Ogrin, M., 2009. Razvoj in vloga cestnega prometa. V: Okoljski učinki prometa in turizma v Sloveniji (GeograFF 5). Ljubljana, Znanstvena založba Filozofske fakultete, str. 22-45.

Ogrin, M., 2008. Prometno onesnaževanje ozračja z dušikovim dioksidom v Ljubljani (GeograFF 1). Ljubljana, Znanstvena založba Filozofske fakultete, 87 str.

Ogrin, M., 2007. Air pollution due to road traffic in Ljubljana. Dela, 27, str. 199-214.

Ogrin, D., Ogrin, M., Čemas, D., Planinšek, A., 2006. Prometno onesnaževanje ozračja v Ljubljani znotraj avtocestnega obroča. Končno poročilo raziskovalnega projekta. Ljubljana, Filozofska fakulteta, Oddelek za geografijo, 73 str. 
Palatinus, A., 2009. Vdihni Ljubljano. Spremno besedilo k strokovni razstavi o kakovosti zraka v Ljubljani. URL: http://www.lukatarina.net/Vdihni_Ljubljano/VDIHNI_LJUBLJANO_spremno\%20besedilo.pdf (Citirano 22. 11. 2013).

Palmes, E. D., Gunnison, A. F., DiMattio, J., Tomczyk, C., 1976. Personal sampler for nitrogen dioxide. American Industrial Hygiene Association Journal, 37, 10, str. 570-577.

Plut, D., 2007. Ljubljana in izzivi sonaravnega razvoja. Ljubljana, Filozofska fakulteta, Oddelek za geografijo, $183 \mathrm{str}$.

Rode, B., 2009. Izpusti dušikovih oksidov. Kazalci okolja v Sloveniji. URL: http://kazalci.arso.gov.si/?data=indicator\&ind_id=161 (Citirano 5. 11. 2013).

Sector share of nitrogen oxides emissions (EEA member countries). European Environment Agency. 2012. URL: http://www.eea.europa.eu/data-and-maps/figures/sector-share-of-nitrogen-oxides-emissions-eea-member-countries-3 (Citirano 26. 11. 2013).

Špes, M., Lampič, B., Smrekar, A., 2000. Kvaliteta bivalnega okolja v Ljubljani. V: Gabrovec, M., Orožen Adamič, M. (ur.). Ljubljana: geografija mesta. Ljubljana, LGD, Založba ZRC, str. 163-174.

Vintar Mally, K., 2009. Zaznavanje prometa kot pritiska na okolje na izbranih območjih Slovenije. V: Okoljski učinki prometa in turizma v Sloveniji (GeograFF 5). Ljubljana, Znanstvena založba Filozofske fakultete, str. 73-85.

\section{THE COMPARISON OF SUMMER AIR POLLUTION BY NITROGEN DIOXIDE IN LJUBLJANA BETWEEN 2005 AND 2013}

\section{Summary}

Urban areas have a high density of air pollution sources due to the concentration of population and human activities. Therefore, it is no coincidence that the first written record about air pollution problems referred to the urban areas. Slovene cities are no exception. Even more, generally weak winds and frequent temperature inversions contribute to their greater exposure to traffic-related air pollution in comparison with some other European cities. The most typical example of such conditions is the city of Ljubljana, its air quality being presented in this paper. The air pollution in Ljubljana is nowadays mainly caused by transportation, heat production in residential buildings and heating plants, while the impact of manufacturing activities is relatively low.

The article compares the results of nitrogen dioxide measuring campaigns in Ljubljana in the summers of 2005 and 2013 and seeks to explain the reasons for the differences in the pollution of diverse urban space types. Already in 2005, the diffusive samplers have proved suitable for air quality monitoring and have been therefore also used in 2013. This method can be used not only to measure nitrogen dioxide but also some other pollutants, such as ozone, sulphur dioxide, and benzene. The method is based on the movement of pollutant molecules in the sampler by means of molecular diffusion. Diffusive samplers measure the presence of certain substances in the air using passive sampling method and are accordingly referred to as passive samplers. The samplers are exposed to the outdoor 
conditions and require no air pumping. The sampling rate is controlled by the rate of pollutants diffusion in the air within the sampler, consistent with Fick's diffusion law (explaining also the name of the sampler). Among several types of diffusive samplers, the Palmes samplers have been chosen as they have been often successfully used in similar researches since 1976 (Palmes et al., 1976).

Air quality measurements in urban areas require different spatial methodological approach as compared to rural or uninhabited areas. Urban space is very heterogeneous because many human activities are intertwining and changing at a very short distance. Density, distribution, and type of pollution sources vary widely across the city, causing different levels of air pollution. In order to determine pollution levels within this urban heterogeneity, it is necessary to provide a dense grid of measurements in the different types of urban space. In both summer campaigns, the measuring spots were selected according to three types of urban space: urban background, open space near the roads, and street canyon. Additionally, the measurement of concentrations perpendicular to the main street is presented, illustrating the change in air quality with increasing distance from the main source of pollution.

The comparison of nitrogen dioxide pollution during the summer measuring campaigns in the years 2005 and 2013 shows a significant decrease in concentrations in all types of urban space. The comparison for open space near the roads is based on two measuring spots, while the third is only conditionally usable due to incomplete measurement. In urban background, five measuring spots were compared: three of them revealed a significant decrease in concentration, one measuring spot only a small decline, and the last one even a minor increase in the concentration of nitrogen dioxide $\left(2 \mu \mathrm{g} / \mathrm{m}^{3}\right.$ or $\left.10 \%\right)$. Seven measuring spots were placed inside the street canyons (one measurement in 2013 was incomplete). The comparison reveals a considerable decrease in nitrogen dioxide concentration in all cases, ranging from 4 percent to 39 percent. Nevertheless, the concentrations are still well above the mean annual limit $\mathrm{NO}_{2}$ concentration of $40 \mu \mathrm{g} / \mathrm{m}^{3}$. The nitrogen dioxide concentrations perpendicular to Slovenian Street (i.e. Slovenska cesta, main city street) were similar in both summer campaigns, although in 2013 the concentrations decreased faster with the growing distance from Slovenian Street. Given the high concentrations, about 50 meters from the intersection with the Slovenian Street both streets (Čop Street and Cankar Street) are unsuitable for the bars, shops, and restaurants situated there. Lower nitrogen dioxide concentrations in Ljubljana in summer 2013 (compared to those in summer 2005) can be explained with greater atmospheric dynamics and therefore greater self-cleaning capacity of the atmosphere as well as with a cleaner vehicle fleet.

(Translated by the authors) 